\title{
Towards a more sustainable globalisation: the role of the public health community
}

In her article Fran Baum is correct in pointing out that the political complexities of our globalised world must be taken into account by public health professionals. ${ }^{1}$ Global health futures are directly or indirectly associated with the transnational economic, social, and technological changes taking place in the world. Issues such as poverty, equity, and justice must be firmly rooted in any discussions aimed at improving global public health. However, globalisation is a "janus faced" creature: the double face of globalisation, one promising and the other threatening, is a fact of life as humanity is being catapulted into a more interdependent future. ${ }^{2}$ While Baum maps out a strong argument concerning the threats of globalisation, especially some of the economic threats, she does not pay much attention to important aspects of globalisation that can, potentially, be harnessed by the public health community to reverse negative trends and to forward public health goals. Therefore, rather than expanding the list of "global bads" associated with global interconnectedness, many of which have been enumerated in Baum's analysis, we shall try to tip the balance somewhat by mentioning some of the under-utilised opportunities associated with global change. In this vein, we will briefly mention three perceived opportunities.

Firstly, it is important to emphasise that globalisation is in fact a multifaceted phenomenon. It should not be assumed that the implications of globalisation for public health are all negative. Globalisation is not just "unfettered market liberalism"; but it is the process of increasing economic, political, and social interdependence and global integration that takes place as capital, traded goods, persons, concepts, images, ideas, and values diffuse across state boundaries. ${ }^{3}$ While it is imperative that public health professionals work to minimise the risks and threats associated with globalisation, public health must also take advantage of the opportunities afforded by global change. For instance, the ease and rapidity of communications have facilitated the diffusion of ideas and policy concerns relating to health care and public health (including the spread of diseases across borders) to areas of the world previously beyond the reach of the public health community. ${ }^{2}$ Making these modern information technologies accessible and affordable in the poorest communities in the world will require special initiatives and should be conceived as a globalisation mission statement for the public health community. Furthermore, besides simply dividing states, globalisation is also bringing states together and forcing them to collaborate in ways they never have in history. Shared problems such as climate change, environmental health issues, the spread of infectious diseases, trafficking of illicit drugs, and ethical issues surrounding technological developments such as cloning cannot be tackled through unilateral efforts. ${ }^{4}$ In addition, interdependence leading to "mutual vulnerability" - where ill health, poverty, and the poorest disenfranchised communities in the world pose direct threats to communities in highly developed countries - is forcing developed countries to reconsider their own interests and needs in reducing poverty and inequity in ways they never had to before. ${ }^{5}$ What is clear is that global markets cannot survive and prosper in the midst of social chaos; it is in the self interest of rich countries to ensure that disenfranchised communities and nations of the world do not become political vacuums of chaos in a globalising world.
Secondly, public health professionals must have realistic and effective instruments at hand to ensure that globalisation leads to a more "healthy" development throughout the world. Civil unrest, while important at times, is not an effective avenue towards the development of global public health, nor is the abolishment of the World Trade Organisation (WTO). While countries such as China, as Baum points out, have achieved redistribution in the face of relative poverty, it is also avidly embracing the opportunities of globalisation and the potential benefits of entry to the global trading club, the WTO. The policy environment in which the public health community is working in the $21 \mathrm{st}$ century is one in which the trend towards globalisation of markets has gained an unprecedented momentum in world history. With 135 members and approximately 31 countries in the accession process, the single package of the WTO trade agreements are among the most binding international legal agreements ever implemented. Only by working within the political structures and norms that govern the international system can the public health community make major steps towards reducing the global burden of disease. ${ }^{6}$ We should be striving towards the attainment of a more sustainable form of globalisation; in this regard, it is crucial that public health issues are given a higher profile in international trade deliberations. ${ }^{7}$ It is up to the public health community to gather the solid evidence capable of convincing WTO member states, which also happen to be member states of WHO, that it is in their political interests to implement equitable and healthy trade policies. Moreover, public health professionals must be creative and offer specific policy options, based upon sound scientific evidence, which will have a positive effect on health and will still fit within the structure of existing international society.

Finally, much of the public health community is increasingly seeing itself as a political actor capable of influencing world affairs and is carving out a role for itself in combating poverty, inequity, and unsustainable development. Not only must politics be on the health agenda, but health must also be on the political agenda. In contrast with Baum's assertion, the WHO has shown progressive new leadership in this direction. For example, the WHO member states are currently involved, for the first time in the history of the $\mathrm{WHO}$, in formal negotiations of a binding international law to assist in regulating the devastating health impact of tobacco companies whose actions and products deliberately harm global public health. ${ }^{8}$ The Framework Convention on Tobacco Control process is spreading the health message to numerous government ministries, including foreign affairs, finance, and trade. In addition, the convention process has led to new governance initiatives that the public health community has not used before, including public hearings to represent the voice of civil society, inquiries aimed at increasing the transparency and accountability of global transnational actors, and innovative advocacy initiatives linking local to global spheres of political action. It is hoped that the Framework Convention on Tobacco Control can act as a pathfinder for international health cooperation and action in the future. ${ }^{9}$ Questions of how to create a socially regulated global capitalism, rather than an anarchic unregulated system, are becoming part of the mainstream global social policy debate. In the evolution of social policies to tackle the 
negative externalities of globalisation, public health problems need to be considered as an integral part of the globalisation paradigm debate..$^{10}$ The Framework Convention on Tobacco Control represents a global social policy tool to combat the ill effects of globalisation.

In addition, it is important to note that the importance of equity in health has not lost its political credence or platform since the days when Health for All for year 2000 was promulgated in 1978 in Alma Ata. In May 1995, the member states of WHO recognised that the goals agreed to in Alma Ata would not be attained by year 2000. Accordingly, the World Health Assembly, the governing organ of WHO, adopted a resolution stipulating that a new global health policy for Health for All in the 21 st century be developed. This led to a three year consultative process and the adoption of a World Health Declaration giving effect to the new Health for All Policy in the 21 st century. ${ }^{11}$ The Alma Ata declaration and Health For All for year 2000 focused on the national domain of health policy and action, and did not include transnational dimensions or the need for implementation of global public goods for health. The Health for All Policy for the 21st century notes that, although the 21 st century brings with it new threats and opportunities, new approaches to overcome them are also becoming available. The policy recognises that the globalisation of trade, travel, technology, and communication could yield substantial benefits, provided that serious adverse effects are resolved. The foundational role of certain values is emphasised in the updated Health for All policy. These core values are: recognition that the enjoyment of the highest standard of health is a fundamental human right (the right to health); continued and strengthened application of ethics to health policy, research, and service provision; implementation of equity oriented policies and strategies that emphasise solidarity; and incorporation of a gender perspective into health policies and strategies. Moreover, a major strand of the policy document addresses the issue of the role of the state in public health. A principal recommendation is that governments need to ensure equitable access to essential public health functions (EPHFs) and that the delivery of EPHFs should be tailored to different national and local circumstances. ${ }^{12}$

Furthermore, the Commission on Macroeconomics and Health $(\mathrm{CMH})$ was established in January 2000 by Dr Gro Harlem Brundtland, director general of the WHO, in response to the need to place health at the centre of the development agenda. The rationale for this commission's work is that the world economy is at a crossroads: globalisation moves apace and generates real benefits; but actions are required to ensure that these benefits do not exclude the world's one and a half billion poor. Ensuring that people, particularly the poor, enjoy better health is an important factor in improving the economic wellbeing of populations in general and in reducing poverty in particular.

In summary, it is our belief that important challenges face the public health community and, indeed, humanity in an increasingly globalised world. Some of these challenges, it is true, threaten the very stability and social cohesion of societies from local to global levels. However, tackling the inequities and contradictions of globalisation does not mean that it must be dismantled plank by plank. Obliterating global interconnectedness in preference for autarchic, disconnected economic nations and units would surely lead to a Hobbesian state of nature and global chaos. We have seen from the 1970s that experiments of de-linking from the global economy proved to be both unworkable and harmful. Therefore, we contend that the global public health community should strive towards the realisation of a more sustainable form of globalisation in the 21 st century. The evolution of global business ethics will be an integral part of a more sustainable global future. Such ethics will be predicated on the recognition that ethical climates are a prerequisite for lasting global competitiveness and should focus on environmental and socially responsible activities. ${ }^{13}$

With regard to the economic aspects of globalisation, we have emphasised that markets cannot thrive in a political vacuum. As Amartya Sen has recently noted there is indeed a close connection between economic progress and health achievement, and it would be foolish to take health to be independent of economic means .... There is much merit in economic progress, but there is also an overwhelming role for intelligent and equitable social policies. ${ }^{14}$

We in the public health community should be integrally involved in shaping these more intelligent and equitable social policies. In so doing, our strategies must confront the threats of globalisation, while not losing sight of the opportunities.

DOUGLAS W BETTCHER HEATHER WIPFLI

Framework Convention on Tobacco Control Team, Tobacco Free Initiative, World Health Organisation, Geneva, Switzerland (Bettcherd@who.ch)

1 Baum F. Health, equity, justice and globalisation: some lessons from the People's Health Assembly. $\mathcal{F}$ Epidemiol Community Health 2001;55:613-6.

2 Yach D, Bettcher D. The globalization of public health I: Threats and opportunities. Am f Public Health 1998;88:735.

3 Hurrel A, Woods N. Globalization and inequality. Millennium fournal of International Studies 1995;24:447-70.

International Studies 1995;24:447-70.
4 World Health Organisation. Health informatics and telemedicine. WHO World Health Organisation. Health informatics and telemedicine. WHO
Document EB99/INF.DOC./9. Geneva: World Health Organisation, 1997. 5 Yach D, Bettcher D. The globalization of public health II: The convergence of self-interest and altruism. Am f Public Health 1998;88:738-41.

6 Bettcher D, Shaprio I. Tobacco control in an era of trade liberalisation. Tobacco Control 2001;10:65-7.

7 Bettcher DW, Yach D, Guindon E. Global trade and health: key linkages and future challenges. Bull World Health Organ 2000;78:521-35.

8 Taylor AL, Bettcher DW. WHO Framework Convention on Tobacco Control: a global good for public health, Bull World Health Organ 2000;78: 920-30.

9 Subramaniam C. Advocacy for policy change. NGO and Media Workshop. Geneva: WHO, 1998.

10 Yach D, Bettcher D. Globalisation of tobacco industry influence and new global responses. Tobacco Control 2000;9:206-16.

11 World Health Organisation. Health for All in the twenty-first century. Document WHA51/5. Geneva: WHO, 1998.

12 Bettcher DW, Sapirie S, Goon EHT. Essential public health functions: results of the international Delphi study. World Health Stat Q 1998;51:4454

13 Bettcher D, Yach D. The globalisation of public health ethics? Millennium fournal of International Studies 1998;27:469-96.

14 Sen A. Economic progress and health. In: Leon D, Walt G, eds. Poverty, inequality, and health. Oxford: Oxford University Press, 2001. 